\title{
Different somatic alterations of the HRPT2 gene in a patient with recurrent sporadic primary hyperparathyroidism carrying an HRPT2 germline mutation
}

\author{
F Cetani ${ }^{1}$, E Pardi ${ }^{1}, E$ Ambrogini ${ }^{1}, P$ Viacava $^{2}, S$ Borsari $^{1}, M$ Lemmi $^{1}$,

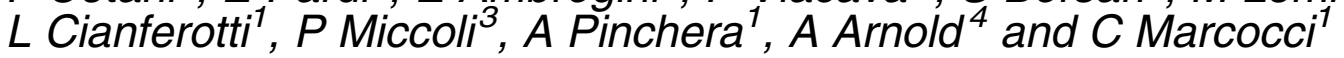

\begin{abstract}
Departments of ${ }^{1}$ Endocrinology and Metabolism, ${ }^{2}$ Oncology, Section of Pathology and ${ }^{3}$ Surgery, University of Pise, Pise, Italy ${ }^{4}$ Center for Molecular Medicine and Division of Endocrinology \& Metabolism, University of Connecticut School of Medicine, Farmington, Connecticut, USA
\end{abstract}

(Requests for offprints should be addressed to F Cetani; Email: cetani@endoc.med.unipi.it)

\begin{abstract}
Early onset of primary hyperparathyroidism (PHPT) and multiglandular involvement suggest a familial form in which germline mutation of a PHPT-related gene(s) and a somatic event at the same locus can be often demonstrated. We investigated the involvement of multiple endocrine neoplasia type 1 (MEN1) and HRPT2 genes in a 39-year-old man with recurrent PHPT. PHPT was firstly diagnosed at the age of 21 and the patient had two recurrences separated by extended periods of normocalcemia. This unusual history prompted us to investigate other family members and study the MEN1 and HRPT2 genes. An HRPT2 germline missense mutation in exon 3 (R91P) was found in the index case, which was associated with different HRPT2 somatic alterations in each of the three examined parathyroid tumors. These findings are consistent with Knudson's 'two hit' concept of biallelic inactivation of classical tumor suppressor genes. Screening of 15 asymptomatic relatives was negative for the R91P germline mutation. All the three abnormal parathyroid specimens showed cystic features at histology and were negative for parafibromin immunostaining. In one specimen, diffuse parafibromin staining was evident in a rim of normal parathyroid tissue surrounding the adenomatous lesion. Our study shows that different somatic genetic events at the HRPT2 locus are responsible for the asynchronous occurrence of multiple adenomas in a patient carrying an HRPT2 germline mutation. The finding of diffuse parafibromin staining in a rim of normal parathyroid tissue, but not in the contiguous adenomatous lesion, reinforces the concept that loss of parafibromin expression is responsible for the development of parathyroid tumors in this setting.
\end{abstract}

Endocrine-Related Cancer (2007) 14 493-499

\section{Introduction}

Primary hyperparathyroidism (PHPT) is one of the most common endocrine disorders, especially in postmenopausal women in whom it reaches a prevalence of $2-3 \%$ (Adami et al. 2002). A single, benign parathyroid adenoma is responsible for sporadic PHPT in $80-85 \%$ of cases, the remaining being caused by multiple adenomas, hyperplasia of all parathyroid glands, and rarely by carcinoma (Marx 2000). On the other hand, multiglandular involvement is typically found in familial forms of PHPT, namely multiple endocrine neoplasia types 1 and 2A (MEN 1 and MEN 2A), hyperparathyroidism-jaw tumor syndrome (HPT-JT), or familial isolated hyperparathyroidism (FIHP) (Marx et al. 2002). These inherited forms of PHPT typically present at an earlier age than sporadic forms of PHPT and occur with equal frequencies in both sexes. Thus, the finding of multiglandular involvement at surgery or recurrence of PHPT in the same individual, particularly in a young subject, could suggest a hereditary syndrome.

The identification of genes responsible for familial PHPT (MEN1, HRPT2, CASR, and RET genes) has 
increased our knowledge about parathyroid tumorigenesis (Chandrasekharappa et al. 1997, Carpten et al. 2002, Marx et al. 2002). MEN1 and HRPT2 function as tumor suppressor genes, consistent with the Knudson 'two hit' hypothesis. The second hit often causes loss of heterozygosity ( $\mathrm{LOH})$ of a large chromosomal region, as in the majority $(\sim 70-90 \%)$ of MEN1associated tumors (Larsson et al. 1988, Friedman et al. 1989, Thakker et al. 1989, Pannett \& Thakker 2001), but other mechanisms such as smaller deletions and point mutations that may also inactivate the gene, can occur and seem to be preferentially involved in HRPT2-related tumors ( 30-50\%; Arnold et al. 2002, Carpten et al. 2002, Howell et al. 2003, Shattuck et al. 2003, Cetani et al. 2004, Villablanca et al. 2004, Moon et al. 2005, Bradley et al. 2006, Kelly et al. 2006, Mizusawa et al. 2006). Hereditary syndrome when compared with sporadic parathyroid tumors shows early onset age and multiplicity, because each parathyroid cell has 'one hit' by inheritance. Thus, subtotal or total parathyroidectomy is usually performed for the cure of familial PHPT, whereas the excision of the single diseased gland is sufficient in most cases of sporadic PHPT.

In this report, we describe a 39-year-old man with sporadic PHPT, who had two recurrences after successful surgery over a 17-year follow-up. This unusual history prompted us to perform genetic studies, which led to the identification of a HRPT2 germline mutation associated with independent HRPT2 somatic alterations (mutations or $\mathrm{LOH}$ at the same locus) in the different parathyroid tumors.

\section{Materials and methods}

\section{Case report}

The proband, a 39-year-old man, referred to our Department in February 1998 for recurrent sporadic PHPT. In 1987, at the age of 21 years, a severe form of PHPT was diagnosed (serum calcium $17.3 \mathrm{mg} / \mathrm{dl}$ (normal range 8.2-10.2); C-PTH $3.17 \mathrm{ng} / \mathrm{ml}$ (< $0.88 \mathrm{ng} / \mathrm{ml}$ ), and osteitis fibrosa cistica). On surgery, a 3-cm right inferior (RI) parathyroid gland was removed. Three additional parathyroid glands were identified and showed a normal appearance; a biopsy of the left superior (LS) parathyroid was carried out. Histological examination showed a RI parathyroid adenoma and normal parathyroid tissue of the LS gland. Three years later, in 1990, recurrence of PHPT was documented but no treatment was advised. In 1993, the patient underwent cervical exploration and a $1.5 \mathrm{~cm}$ right superior (RS) parathyroid gland was excised and both left glands appeared grossly normal. Histology revealed an oxyphilic adenoma. Serum calcium and PTH remained normal until 1997 when a further recurrence of PHPT was documented and the patient referred to our department. The patient was in good health. Serum calcium and PTH were mildly elevated $(10.6 \mathrm{mg} / \mathrm{dl}$ and $72 \mathrm{pg} / \mathrm{ml}$ (normal range 1065) respectively). There was no evidence of MEN1associated neoplasia. No kidney lesions or jaw tumor were detected. Parathyroidectomy was advised, but the patient was lost to follow-up until 2004, when he was referred again to our department. The patient was in good general condition. No cutaneous lesions were evident at physical examination. Serum total and ionized calcium $(12.2 \mathrm{mg} / \mathrm{dl} \quad(2.70 \mathrm{mmol} / \mathrm{l})$ and $5.5 \mathrm{mg} / \mathrm{dl} \quad(1.75 \mathrm{mmol} / \mathrm{l})$ respectively), $\mathrm{PTH}$ $(260 \mathrm{pg} / \mathrm{ml})$, and markers of bone turnover were elevated. Prolactin (PRL), growth hormone (GH), insulin-like growth factor-I (IGF-I), thyroid-stimulating hormone (TSH), adrenocorticotrophic hormone (ACTH), cortisol, follicle-stimulating hormone (FSH), luteinizing hormone ( $\mathrm{LH})$, insulin, gastrin, vasoactive intestinal polypeptide (VIP), glucagon, serotonin, adrenalin, noradrenalin and glucose concentrations were within the normal range. Neck imaging studies (ultrasound, 99m-Tc-sestamibi scan and computerized tomography (CT)) showed two enlarged parathyroids in the left side of the neck. No pancreatic or adrenal lesions were found by ultrasound or CT. Chest X-ray and CT were normal. Orthopantography of the jaw was negative. The patient was submitted to surgery with removal of the LS $(1.5 \mathrm{~cm})$ and left inferior (LI; $1.0 \mathrm{~cm}$ ) parathyroid glands. Histological examination showed chief cell adenomas. After a transient hypocalcemia, serum calcium and PTH remained normal until March 2006.

Fifteen first degree relatives were available for further investigations. Serum calcium and PTH were in the normal range in all cases.

Informed consent was obtained from the patient and his relatives for all procedures used in the present study. The study was approved by the local ethical committee.

\section{Methods}

\section{Tissue samples}

Tissues were obtained at the time of surgery, immediately snap frozen in liquid nitrogen and stored at $-80{ }^{\circ} \mathrm{C}$ until use. Tissue sample of the RI parathyroid gland was not available. 


\section{Genetic studies}

Genomic DNA was isolated from peripheral blood leukocytes and parathyroid tissues by the standard proteinase K-SDS digestion and the phenol/chloroform method. Allelic deletions and direct sequencing of HRPT2 and MEN1 genes were assessed in both blood leukocytes and tumor DNAs as described previously (Cetani et al. 2004). Nucleotide sequences were determined on double strands at least twice. The intragenic polymorphisms in introns 10 and 14 of the HRPT2 gene and the microsatellite markers (PYGM and D11S449) flanking the MEN1 gene were used. The region of interest of the HRPT2 gene was also amplified using constitutional DNA of all family members and 55 unrelated controls of Italian origin (110 chromosomes). The sequence abnormality found in the constitutional DNA was confirmed by restriction enzyme analysis.

\section{Immunohistochemistry}

Sections of the left parathyroid tumors were deparaffinized in xylene and rehydrated in alcohol. Endogenous peroxide activity was blocked by incubating the slides in $1 \%$ hydrogen peroxide in methanol for $10 \mathrm{~min}$. In order to unmask the antigen, the slides were microwave-treated in $10 \mathrm{mM}$ citrate buffer, $\mathrm{pH} 6.0$ for $10 \mathrm{~min}$. After blocking nonspecific staining with normal serum, the sections were incubated for $1 \mathrm{~h}$ with the primary anti-parafibromin monoclonal antibody (Tan et al. 2004; kindly donated by Bin Tean Teh), which was used at 1:50 dilution. This antibody is directed against the portion of the protein corresponding to amino acid positions $87-100$. The sections were then incubated with biotin-labeled secondary antibody (dilution 1:500) and avidin-biotin complex (Vector Laboratories, Burlingame, CA, USA) for $30 \mathrm{~min}$ each. Sites of binding were visualized using 3,3-diaminobenzidine as chromogen. Finally, sections were counterstained with hematoxylin, dehydrated, and mounted. The positive control was normal parathyroid and two negative controls included experiments omitting primary antibody or using primary antibody pre-absorbed with a 20 -fold excess of the immunizing peptide. For each case, six different sections were analyzed.

Tumors were scored as positive if specific nuclear staining was detected and the staining was quantified according to the percentage of positive cells, independently of the intensity of staining (Cetani et al. 2007). Tumors were scored as negative when no tumor cells showed a specific nuclear staining.

\section{Results}

\section{Genetic studies}

All tissue specimens were heterozygous for the MENI gene flanking markers DIIS449 and PYGM, thus indicating the absence of large chromosomal deletions. Direct sequencing of the MEN1 gene did not reveal any mutation.

Results of HRPT2 gene are summarized in Table 1 and shown in Fig. 1. LOH of both intragenic markers was identified in the LS parathyroid specimens. Retained heterozygosity was present in the other parathyroid samples. Sequence analysis of PCRamplified tumor and germline DNAs revealed two missense (R91P and A2S) and one nonsense (Y54X) HRPT2 mutations. The R91P mutation was germline; the A2S mutation was found only in the LI gland, and the Y54X only in the RS. The latter mutation has been previously reported in a parathyroid cancer (Howell et al. 2003, Shattuck et al. 2003). The two missense mutations alter evolutionarily conserved amino acids (alanine to a serine and arginine to a proline). The substitution of the nonpolar hydrophobic alanine for a polar hydrophilic serine in the A2S mutation and of an arginine for a helix-breaker proline in the $\mathrm{R} 91 \mathrm{P}$ mutation may likely lead to deleterious structural alterations of parafibromin that may affect its function.

The R91P germline mutation led to the loss of a TaqI site providing a convenient diagnostic test to confirm the presence of mutation in the proband and to demonstrate its absence in the other family members and 55 control DNAs. As indicated in Fig. 1, digestion of a fragment of exon 3 containing the R91P mutation with TaqI produced a 163 (mutant allele), 85 and $78 \mathrm{bp}$ (wild-type allele) fragments. All relatives were also screened for the mutation by sequencing. The R91P mutation was absent in the patient's mother and sister and in three paternal first-degree cousins. We could not investigate the father because he was deceased, but the paternal grandfather

Table 1 Genetic studies in parathyroid tissues

\begin{tabular}{lll}
$\begin{array}{l}\text { Parathyroid } \\
\text { gland }\end{array}$ & \multicolumn{1}{c}{$\begin{array}{c}\text { HRPT2 } \\
\text { sequence }\end{array}$} & LOH HRPT2 locus \\
\hline $\begin{array}{l}\text { Right inferior } \\
\text { Right superior }\end{array}$ & NA & Y54X Somatic \\
& R91P Germline & Retention \\
Left inferior & A2S Somatic & Retention \\
& R91P Germline & \\
Left superior & R91P Germline & LOH
\end{tabular}

${ }^{a}$ Intragenic markers in introns 10 and 14 were studied (Shattuck et al. 2003).

${ }^{\mathrm{b}}$ Not available. 
A

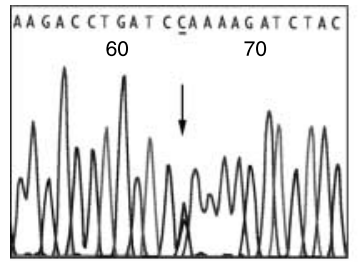

Germline R91P

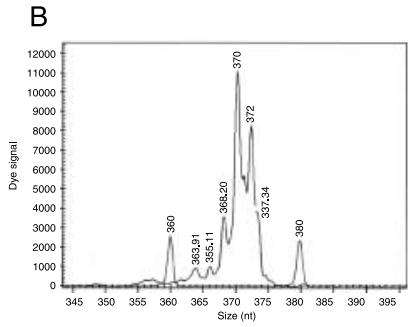

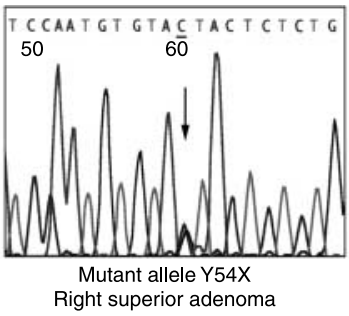
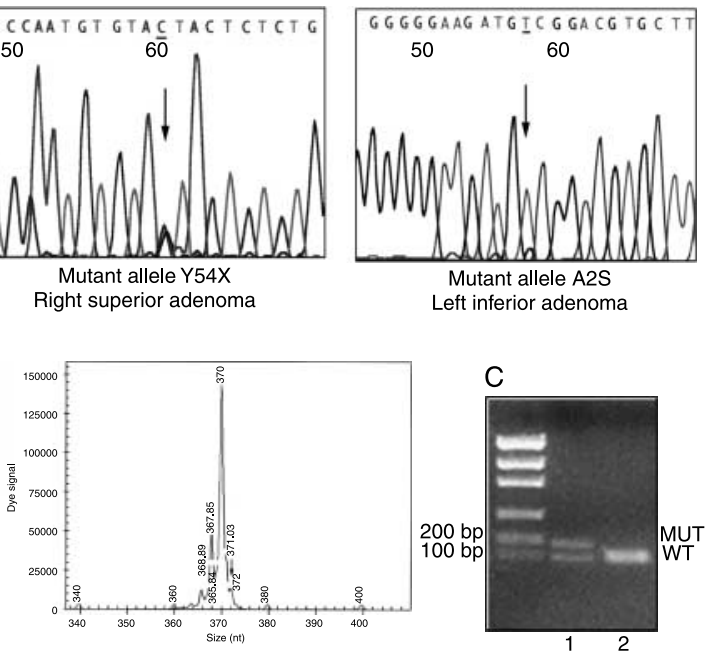

Figure 1 Mutational analysis, $\mathrm{LOH}$, and restriction enzyme analyses of HRPT2 gene. (A) Sequencing chromatograms. Left panel: heterozygous R91P germline mutation in exon 3 (CGA >CCA); middle panel: heterozygous Y54X somatic mutation detected in the RS adenoma (TAC>TAG); right panel: heterozygous A2S somatic mutation detected in the LI adenoma (GCG $>$ TCG). (B) LOH analysis. Tumor DNA shows a LOH (arrow) using intron 10 polymorphism. (C) Detection of a R91P mutation in exon 3 by restriction endonuclease analysis. The mutation results in the loss of a Taq/ restriction enzyme site. Following PCR with appropriate primers of a fragment of exon 3 and cleavage with Taql, a band of $163 \mathrm{bp}$ (mutant allele) and two bands of 85 and 78 bp are shown in the patient (lane 1) and only the latter bands in the control subject (lane 2). The positions of the size markers at 100 and 200 bp are indicated.

and all the father's six siblings were negative. These data suggest that the R91P germline mutation occurred de novo in our patient. This mutation was not detected in the patient's three sons.

\section{Immunohistochemistry}

Normal parathyroid gland was used as the positive control and showed a diffuse nuclear staining in $\sim 90 \%$ of chief cells, without staining of adipose and connective tissue or blood vessels. All abnormal parathyroid specimens showed cystic features and were negative for parafibromin expression (Fig. 2). Interestingly, parafibromin staining was retained in a rim of normal parathyroid tissue surrounding the LI adenoma. The percentage of positive cells and the intensity of staining were comparable to those observed in the normal parathyroid gland.

\section{Discussion}

The medical history and the apparent success of initial surgery (RI parathyroidectomy) were consistent with the diagnosis of sporadic PHPT due to a single parathyroid adenoma, but the subsequent follow-up has clearly shown that this was not the case. Indeed, the patient had two recurrences of PHPT, which occurred 3 and 4 years after normalization of serum calcium and PTH, in both cases following the excision of a single enlarged parathyroid gland, with a histological picture of adenoma. Moreover, in both occasions, evidence of histologically normal parathyroid tissue was available. Thus, after the second adenomectomy, which was followed by normocalcemia, it was reasonable to believe that the patient was affected by double parathyroid adenomas. However, as mentioned before, a further relapse of PHPT occurred and, at this time, two enlarged parathyroid glands were removed and chief cell adenomas were found at histology.

The early presentation of PHPT and the evidence of subsequent multiglandular involvement, despite the absence of family history and other associated syndromic manifestations, suggested a possible hereditary form of PHPT. We studied the MEN1 and HRPT2 genes, although we would not have had as high an expectation for MEN1, since the asynchrony, the 'one adenoma at a time' presentation and the presence of cystic changes in parathyroid tumors suggest the involvement of the HRPT2 gene rather than the MEN1 gene. We found a HRPT2 germline mutation, which was paired with different acquired genetic abnormalities in the three abnormal parathyroid glands we studied. Interestingly, the HRPT2 germline mutation was missense. Nonsense or frameshift mutations, resulting in truncated proteins, usually occur in the HPT-JT syndrome and parathyroid cancer (Carpten et al. 2002, Howell et al. 2003, Shattuck et al. 

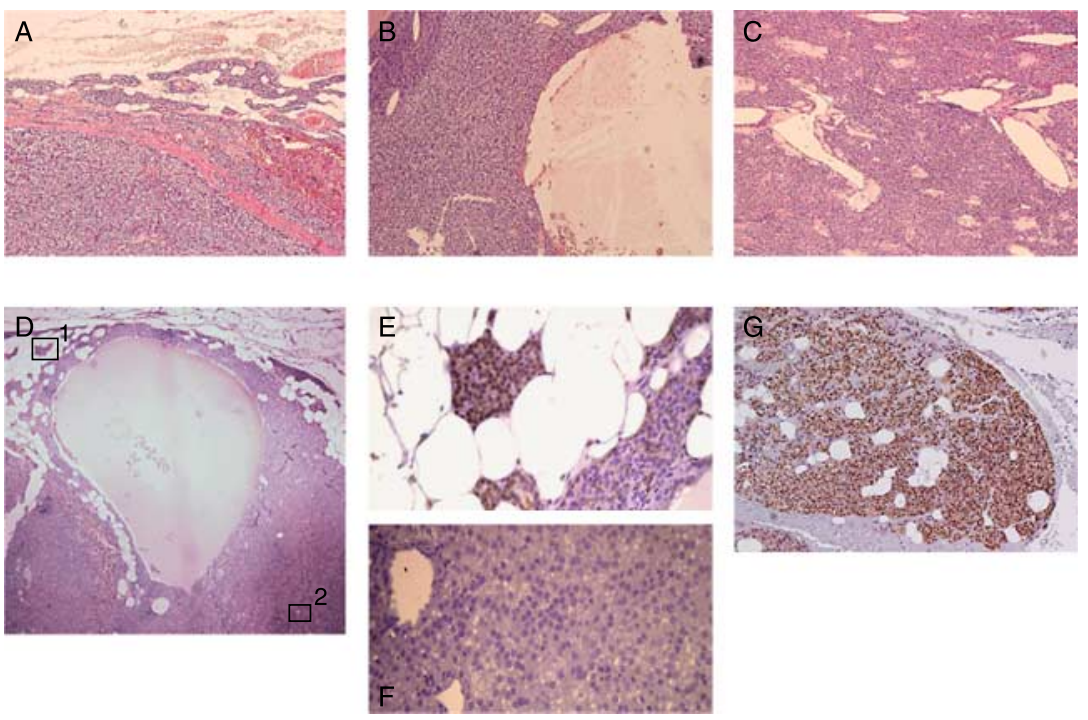

Figure 2 Histology (upper panels) and parafibromin staining (lower panels). (A) The adenomatous tissue and a rim of normal tissue separated by the capsule are shown (LI parathyroid adenoma, hematoxylin-eosin, $\times 100)$. (B) Large cystic lesion of LI parathyroid adenoma (hematoxylin-eosin, $\times 100$ ). (C) Multiple cystic lesions of LS parathyroid adenoma (hematoxylin-eosin, $\times 100)$. (D) Low magnification of the $\mathrm{LI}$ parathyroid adenoma showing a rim of normal parathyroid tissue (immunohistochemistry, $\times 40$ ). $(\mathrm{E})$ Magnification of inset 1 of panel D showing a diffuse nuclear immunoreactivity of normal parathyroid tissue surrounding the adenoma (immunohistochemistry, $\times 400)$. (F) Magnification of inset 2 of panel D showing absence of nuclear immunoreactivity of adenomatous tissue (immunohistochemistry, $\times 400$ ). (G) Normal parathyroid gland showing a diffuse nuclear immunoreactivity (immunohistochemistry, $\times 200$ ).

2003, Cetani et al. 2004, Bradley et al. 2006). It has been hypothesized that missense mutations, resulting in abnormal proteins, may have a lower phenotypic penetrance. As a matter of fact, an association between MEN1 gene missense mutations and FIHP has been reported by Pannett \& Thakker (2001). A similar HRPT2 mutation spectrum has been suggested in FIHP versus HPT-JT. Indeed, an overall analysis of the HRPT2 germline mutations identified by this study together with the 11 previously reported in FIHP (Carpten et al. 2002, Howell et al. 2003, Cetani et al. 2004, Simonds et al. 2004, Villablanca et al. 2004, Bradley et al. 2005a,b, 2006, Guarnieri et al. 2006, Kelly et al. 2006, Mizusawa et al. 2006) reveals that $16.7 \%$ are missense mutations as opposed to $9.5 \%$ in HPT-JT (Carpten et al. 2002, Howell et al. 2003, Bradley et al. 2005b, 2006, Moon et al. 2005, Aldred et al. 2006, Mizusawa et al. 2006, Yamashita et al. 2007). Thus, the presence of a missense mutation might explain the absence of an obvious family history in apparently sporadic PHPT patients. This is in keeping with the findings in our patient, in whom, despite the R91P germinal HRPT2 mutation, no other phenotypic features of classical HPT-JT were present. On the other hand, this mutation might have increased parathyroid proliferation and therefore the risk of additional somatic events, responsible for the asynchronous development of parathyroid gland abnormalities in our patient. Indeed, different HRPT2 gene somatic alterations were found in each individual excised gland. Asynchronous somatic events may account for the usual clinical history of recurrent PHPT in HPT-JT, in which each recurrence occurs as a single gland disease, separated by periods of normocalcemia. The importance of a second somatic hit at the HRPT2 locus in the pathogenesis of parathyroid adenomas in our patient is strongly supported by the finding of positive parafibromin staining in a small rim of normal tissue surrounding the LI adenoma.

Only one study has investigated genetic alterations in multiple tumors occurring in the same patient with sporadic PHPT (five cases of double adenomas; Dwight et al. 2002). The tumors were examined for $\mathrm{LOH}$ at distal 1p, HPT-JT locus at 1q-21-32 and flanking regions, and MEN1 locus at 11q13. Different genetic events were found in paired glands. While LOH was found in one gland, the other gland showed either $\mathrm{LOH}$ in another locus or no allelic loss. In particular, three tumors had $\mathrm{LOH}$ at 11q13 associated with a somatic MEN1 mutation in the other allele, but not in the germline DNA.

The HRPT2 germline mutation found in the present study involves amino acid 91 and, therefore, it is possible that the anti-parafibromin antibody used in the present study, which is directed against amino acids 87-100, may 
not recognize the protein encoded by the germline mutated HRPT2 allele. Thus, the absence of parafibromin staining would not demonstrate its inactivation in the tumor. On the other hand, the replacement of an arginine for a helixbreaker proline suggests parafibromin inactivation.

Our patient had removed four abnormal parathyroid glands, which were asynchronously involved over a 17-year period. The normal serum calcium and PTH after the last surgical procedure suggest the presence of supernumerary parathyroid gland(s). Alternatively, it is possible that the patient has a small amount of locally invasive parathyroid cancer in the right side of the neck, which was not re-explored at the last surgery, or metastatic disease elsewhere. Re-evaluation of all histological sections of right-side tumors by our pathologist (PV) showed no histologic features suggestive of potential malignancy. Since HRPT2 mutation carriers are at risk for recurrence of PHPT or parathyroid cancer, regular follow-up is mandatory in our patient. Frequent surveillance may allow an early detection and cure of PHPT, before a possible development of malignancy (Guarnieri et al. 2006, Kelly et al. 2006).

In conclusion, our study shows that different somatic genetic events at the HRPT2 locus are associated with the asynchronous occurrence of multiple adenomas in a patient carrying an HRPT2 germline mutation. The finding of diffuse parafibromin staining in a rim of normal parathyroid tissue, but not in the adenomatous lesion, further reinforces the concept that loss of parafibromin expression is responsible for the development of such parathyroid tumors.

\section{Acknowledgements}

This work was supported by Grants from the University of Pisa (Fondi di Ateneo per la Ricerca) and the Ministero dell'Istruzione, dell'Università e della Ricerca (Project: Studies of new oncongenes involved in parathyroid tumorigenesis), and the Murray-Heilig Fund in Molecular Medicine (AA). We would like to thank the family that graciously agreed to participate in the study and Prof. Bin Tean Teh, Van Andel Research Institute, Grand Rapids, Michigan, USA, for the generous gift of the monoclonal parafibromin antibody and Pasquale Cofelice for his technical assistance. The authors declare that there is no conflict of interest that would prejudice the impartiality of this scientific work.

\section{References}

Adami S, Marcocci C \& Gatti D 2002 Epidemiology of primary hyperparathyroidism in Europe. Journal of Bone and Mineral Research 17 (Suppl 2) N18-N23.
Aldred MJ, Talacko AA, Savarirayan R, Murdolo V, Mills AE, Radden BG, Alimov A, Villablanca A \& Larsson C 2006 Dental findings in a family with hyperparathyroidism-jaw tumor syndrome and a novel HRPT2 gene mutation. Oral Surgery, Oral Medicine, Oral Pathology, Oral Radiology, and Endodontics 101 212-218.

Arnold A, Shattuck TM, Mallya AM, Krebs LJ, Costa J, Gallacher J, Wild Y \& Saucier K 2002 Molecular pathogenesis of primary hyperparathyroidism. Journal of Bone and Mineral Research 17 (Suppl 2) N30-N36.

Bradley KJ, Hobbs MR, Buley ID, Carpten JD, Cavaco BM, Fares JE, Laidler T, Manek S, Robbins CM, Salti IS et al. $2005 a$ Uterine tumors are a phenotypic manifestation of the hyperparathyroidism-jaw tumor syndrome. Journal of Internal Medicine 257 18-26.

Bradley KJ, Cavaco BM, Bowl MR, Harding B, Young A \& Thakker RV $2005 b$ Utilisation of a cryptic non-canonical donor splice site of the gene encoding PARAFIBROMIN is associated with familial isolated primary hyperparathyroidism. Journal of Medical Genetics 42 e51.

Bradley KJ, Cavaco BM, Bowl MR, Harding B, Cranston T, Fratter C, Besser GM, Conceicao Pereira M, Davie MW, Dudley N et al. 2006 Parafibromin mutations in hereditary hyperparathyroidism syndromes and parathyroid tumours. Clinical Endocrinology 64 299-306.

Carpten JD, Robbins CM, Villablanca A, Forsberg L, Presciuttini S, Bailey-Wilson J, Simonds WF, Gillanders EM, Kennedy AM, Chen JD et al. 2002 HRPT2, encoding parafibromin, is mutated in hyperparathyroidism-jaw tumors syndrome. Nature Genetics 32 676-680.

Cetani F, Pardi E, Borsari S, Viacava P, Dipollina G, Cianferotti L, Ambrogini E, Gazzerro E, Colussi G, Berti $\mathrm{P}$ et al. 2004 Genetic analyses of the HRPT2 gene in primary hyperparathyroidism: germline and somatic mutations in familial and sporadic parathyroid tumors. Journal of Clinical Endocrinology and Metabolism 89 5583-5591.

Cetani F, Ambrogini E, Vacava P, Pardi E, Fanelli G, Naccarato AG, Borsari S, Lemmi M, Berti P, Miccoli P et al. 2007 Should parafibromin staining replace HRPT2 gene analysis as an additional tool for histologic diagnosis of parathyroid carcinoma? European Journal of Endocrinology $156547-554$.

Chandrasekharappa SC, Guru SC, Manickam P, Olufemi SE, Collins FS, Emmert-Buck MR, Debelenko LV, Zhuang ZP, Lubenski IA, Liotta LA et al. 1997 Positional cloning of the gene for multiple endocrine neoplasia-type 1. Science 276 404-407.

Dwight T, Nelson AE, Theodosopoulos G, Richardson AL, Learoyd DL, Philips J, Delbridge L, Zedenius J, Teh BT, Larsson C et al. 2002 Independent genetic events associated with the development of multiple parathyroid tumors in patients with primary hyperparathyroidism. American Journal of Pathology 161 1299-1306.

Friedman E, Sakaguchi K, Bale AE, Falchetti A, Streeten E, Zimering MB, Weinstein LS, McBride WO, Nakamura Y, 
Brandi ML et al. 1989 Clonality of parathyroid tumors in familial multiple endocrine neoplasia type 1. New England Journal of Medicine 321 213-218.

Guarnieri V, Scillitani A, Muscarella LA, Battista C, Bonfitto N, Bisceglia M, Minisola S, Mascia ML, D’Agruma L \& Cole DE 2006 Diagnosis of parathyroid tumors in familial isolated hyperparathyroidism with HRPT2 mutation: implications for cancer surveillance. Journal of Clinical Endocrinology and Metabolism 91 2827-2832.

Howell VM, Haven CJ, Kahnoski K, Khoo SK, Petillo D, Chen J, Fleuren GJ, Robinson BG, Delbridge LW, Philips $\mathrm{J}$ et al. 2003 HRPT2 mutations are associated with malignancy in sporadic parathyroid tumors. Journal of Medical Genetics 40 657-663.

Kelly TG, Shattuck TM, Reyes-Mugica M, Stewart AF, Simonds WF, Udelsman R, Arnold A \& Carpenter TO 2006 Surveillance for early detection of aggressive parathyroid disease: carcinoma and atypical adenoma in familial isolated hyperparathyroidism associated with a germline HRPT2 mutation. Journal of Bone and Mineral Research 21 1666-1671.

Larsson C, Skogseid B, Oberg K, Nakamura Y \& Nordenskold M 1988 Multiple endocrine neoplasia type 1 gene maps to chromosome 11 and is lost in insulinoma. Nature 332 85-87.

Marx SJ 2000 Hyperparathyroidism and hypoparathyroidism disorders. New England Journal of Medicine 343 1863-1875.

Marx SJ, Simonds WF, Agarwal SK, Burns AL, Weinstein LS, Cochran C, Skarulis MC, Spiegel AM, Libutti SK, Alexander HR Jr et al. 2002 Hyperparathyroidism in hereditary syndromes: special expressions and special managements. Journal of Bone and Mineral Research 17 (Suppl 2) N37-N43.

Mizusawa N, Uchino S, Iwata T, Tsuyuguchi M, Suzuki Y, Mizukoshi T, Yamashita Y, Sakurai A, Suzuki S, Beniko M et al. 2006 Genetic analyses in patients with familial isolated hyperparathyroidism and hyperparathyroidismjaw tumour syndrome. Clinical Endocrinology 65 9-16.

Moon SD, Park JH, Kim EM, Kim JH, Han JH, Yoo SJ, Yoon KH, Kang MI, Lee KW, Son HY et al. 2005 A novel IVS2-1G $>$ A mutation causes aberrant splicing of the
HRPT2 gene in a family with hyperparathyroidism-jaw tumor syndrome. Journal of Clinical Endocrinology and Metabolism 90 878-883.

Pannett AA \& Thakker RV 2001 Somatic mutations in MEN type 1 tumors, consistent with the Knudson 'two-hit' hypothesis. Journal of Clinical Endocrinology and Metabolism 86 4371-4374.

Shattuck TM, Valimaki S, Obara T, Gaz RD, Clark OH, Shoback D, Wierman ME, Tojo K, Robbins CM, Carpten JD et al. 2003 Somatic and germ-line mutations of the HRPT2 gene in sporadic parathyroid Carcinoma. New England Journal of Medicine 349 1722-1729.

Simonds WF, Robbinc CM, Agarwal SK, Hendy GN, Carpten JD \& Marx SJ 2004 Familial isolated hyperparathyroidism is rarely caused by germline mutations in HRPT2, the gene for the hyperparathyroidism-jaw tumor syndrome. Journal of Clinical Endocrinology and Metabolism 89 96-102.

Tan MH, Morrison C, Wang P, Yang X, Haven CJ, Zhang C, Zhao P, Tretiakova MS, Korpi-Hyovalti E, Burgess JR et al. 2004 Loss of parafibromin immunoreactivity is a distinguishing feature of parathyroid carcinoma. Clinical Cancer Research 10 6629-6637.

Thakker RV, Bouloux P, Wooding C, Chotai K, Broad PM, Spurr NK, Besser GM \& O'Riordan JL 1989 Association of parathyroid tumors in multiple endocrine neoplasia type 1 with loss of alleles on chromosome 11. New England Journal of Medicine 321 218-224.

Villablanca A, Calender A, Forsberg L, Hoog A, Cheng JD, Petillo D, Bauters C, Kahnoski K, Ebeling T, Salmela P et al. 2004 Germline and de novo mutations in the HRPT2 tumor suppressor gene in familial isolated hyperparathyroidism (FIHP). Journal of Medical Genetics 41 e32.

Yamashita Y, Akiyama T, Mizusawa N, Yoshimoto K \& Goto M 2007 A case of hyperparathyroidism-jaw tumor syndrome found in the treatment of an ossifying fibroma in the maxillary bone. International Journal of Oral and Maxillofacial Surgery 36 365-369. 